\title{
Fragmentation Effects on Soil Aggregate Stability in a Patchy Arid Grassland
}

\author{
Brandon T. Bestelmeyer, ${ }^{1}$ Judy P. Ward, ${ }^{2}$ Jeffrey E. Herrick, ${ }^{3}$ and Arlene J. Tugel ${ }^{4}$ \\ Authors are ${ }^{1}$ Research Ecologist, ${ }^{2}$ Biological Science Technician, and ${ }^{3}$ Soil Scientist, \\ USDA-ARS Jornada Experimental Range, New Mexico State University, Las Cruces, NM 88003; and \\ ${ }^{4}$ Soil Scientist, USDA-NRCS, New Mexico State University, Las Cruces, NM 88003
}

\begin{abstract}
Soil aggregate stability (AS) has been promoted as a primary indicator of soil-surface function and a key metric in stateand-transition models. There are few studies, however, that relate indices of AS to the process of grassland degradation. In a Chihuahuan Desert rangeland, we measured variation in AS across vegetated-bare patch boundaries within six plot types reflecting a hypothesized fragmentation/transition sequence. We also examined wetting front depth and $\mathrm{pH}$ along this sequence. We found that AS exhibited consistent and interpretable variation across the patch boundaries of the different plot types. Average AS was highest in grass patches adjacent to small to medium-sized $(0.5-1.5 \mathrm{~m})$ bare patches and was low in grass patches adjacent to large $(>3 \mathrm{~m})$ bare patches. AS of bare ground was also lowest when bare patches in continuous grassland were large and when bare ground formed an interconnected matrix. Wetting depth after a large storm decreased and $\mathrm{pH}$ increased along the fragmentation sequence. The results suggest that AS has interpretable relationships with grassland fragmentation and transitions among states. Careful attention to patchiness within states and stratification, however, is important and simple classifications of strata, such as "bare interspace" and "plant," may not be sufficient to document variation in soil function.
\end{abstract}

\begin{abstract}
Resumen
La estabilidad de los agregados del suelo (AS) has sido promovida como el principal indicador de la función de la superficie del suelo y una medición clave de los modelos de estados estables y transición. Sin embargo, hay pocos estudios que relacionan índices del AS con el proceso de degradación de los pastizales. En un pastizal del desierto Chihuahuense medimos la variación de AS a través de los limites de parches de vegetación y suelo desnudo dentro de seis tipos de parcelas que reflejan una secuencia hipotética de fragmentacion/transición. También examinamos la profundidad del frente húmedo y $\mathrm{pH}$ a lo largo de esta secuencia. Encontramos que la AS mostró una variación consistente e intrepretable a través de los limites del parche de los diferentes tipos de parcela. La AS promedio fue mayor en los parches de zacates adyacentes a parches de suelo desnudo pequeños o medianos $(0.5-1.5 \mathrm{~m}$ ) y fue menor en los parches de zacates junto a parches grandes de suelo desnudo $(>3 \mathrm{~m})$. El AS del suelo desnudo también fue el menor, cuando los parches fueron grandes dentro de un pastizal continuo y cuando el suelo desnudo formó una matriz interconectada. Después de una fuerte tormenta, la profundidad del frente húmedo disminuyó y el $\mathrm{pH}$ se incrementó a lo largo de la secuencia de fragmentación. Estos resultados sugieren que la AS tiene relaciones interpretables con la fragmentación del pastizal y las transiciones entre estados. Sin embargo, es importante poner una atención cuidadosa al patrón dentro de los estados y estratificación y clasificaciones simples de los estratos, tales como "interespacio desnudo" y "planta," pueden ser no suficientes para documentar la variación en la función del suelo.
\end{abstract}

Key Words: Chihuahuan Desert, infiltration, rangeland health, soil quality, state-and-transition model, threshold, two-phase mosaic

\section{INTRODUCTION}

This work was supported by appropriated funds to the USDA Agricultural Research Service, a cooperative agreement with Bureau of Land Management Las Cruces Field Office, and grants from the National Science Foundation to the Jornada Long-Term Ecological Research Site (DEB 0080412, DEB 0004526).

Mention of a proprietary product does not constitute a guarantee or warranty of the product by USDA or the authors and does not imply its approval to the exclusion of the other products that also may be suitable.

Correspondence: Brandon Bestelmeyer, USDA-ARS Jornada Experimental Range, MSC 3JER Box 30003, New Mexico State University, Las Cruces, NM 88003. Email: bbestelm@nmsu.edu.

Manuscript received 24 October 2005; manuscript accepted 8 May 2006.
Theory and practice suggest that persistent transitions from arid/semiarid grasslands to shrublands or bare areas are governed by changes in soil properties (van de Koppel et al. 1997; Ludwig et al. 2005). Once continuous grass cover is fragmented, exposure of the soil surface to raindrop impact, wind, and overland flow across interconnected bare areas causes erosion (Wilcox et al. 2003). Increased erosion and high oxidation rates deplete soil organic matter, while inputs are reduced due to the absence of plant cover leading to a decline in soil microbial populations that stabilize soil macroaggregates (Tisdall and Oades 1982; Oades 1984; Emerson et al. 1986; Oades and Waters 1991). Consequently, soil structure promoting infiltration breaks down, infiltration 


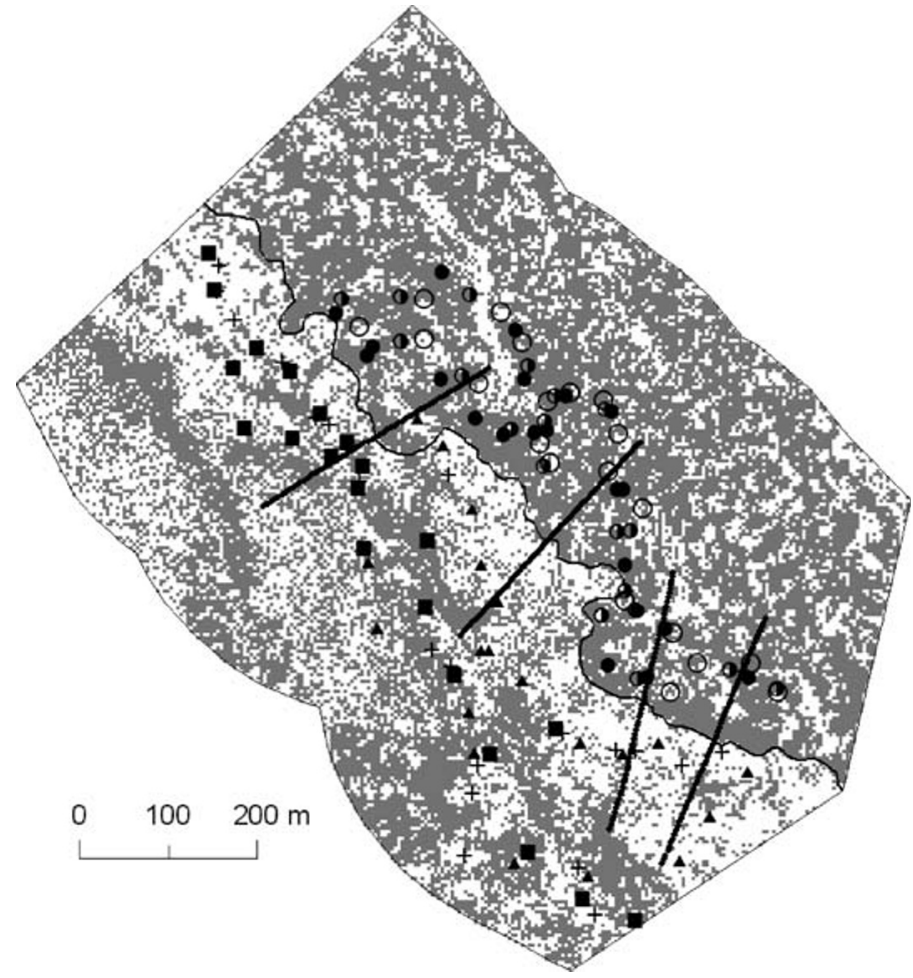

Figure 1. The study area and locations of plots and transects. The study area is defined by a $300 \mathrm{~m}$ buffer around a sharp ecotone (crooked line) separating intact and fragmented areas. Grey areas were classified as vegetated and white areas classified as largely bare ground based on an unsupervised classification of a 1996 U.S. Geological Survey Digital Ortho Quarter Quad ( $1 \mathrm{~m}^{2}$ pixel resolution; see text). These patterns were used in calculating landscape metrics in Table 2. The transects used for measurements of vegetation and soil texture are the 4 straight lines. Plot types are coded as follows: shaded circle = small bare, half-shaded circle $=$ medium bare, open circle $=$ large bare, triangle $=$ shrub/grass mound, square $=$ grass patch, and plus $=$ dead shrub.

rates diminish, and resources to support local grass reproduction decline, feeding back to increase erosion rates (Cerdà 1998). This sequence constitutes a positive feedback producing a transition from grassland to a bare or shrub-dominated state.

The quantitative characterization and detection of vegetation states and transitions using coupled vegetation and soil attributes is a key management strategy in rangelands (Westoby et al. 1989; Bestelmeyer et al. 2003; Briske et al. 2005). Measurements must be rapid and low cost to execute in order to be used in typical management applications involving widespread sampling. Protocols for such measurements have featured a variety of quantifiable vegetation attributes, but few quantifiable soil-surface attributes (Pyke et al. 2002; Tongway and Hindley 2004; Herrick et al. 2005). Of the latter, soil aggregate stability (AS) has emerged as a key attribute because it is easily estimated in the field (see below), and it is positively related to several properties of the soil surface that are related to grassland persistence including resistance to erosion, water infiltration rates, and microbial activity (Tisdale and Oades 1982; Pierson and Mulla 1990; Pierson et al. 1994; Cerdà 1998).

Consequently, estimation of AS via measurements using the "soil stability kit" has been incorporated into recommendations for rangeland assessment and monitoring protocols (Pyke et al. 2002; Karl et al. 2003) as well as Rangeland National Resources Inventory protocols in the United States (Spaeth et al. 2003), and are used in state-and-transition models (STM; Herrick et al. 2002). A similar indicator, the "slake test," is used as part of landscape-scale rangeland assessment protocols (Belnap 1998; Holm et al. 2002; Tongway and Hindley 2004). Despite the widespread use of AS-related indicators to help characterize ecosystem performance, relatively few empirical studies have evaluated such indicators with respect to different vegetation patterns in rangelands (e.g., Holm et al. 2002; Maestre and Cortina 2004). Such studies are needed to evaluate the assumption that AS has interpretable relationships to vegetation transition processes and provides useful information. The primary objectives of this paper are to 1) examine how AS varies with different stages of grassland degradation in an arid rangeland, and 2) to identify particular stages in which AS suggests diminished soil function (i.e., a threshold sensu Freidel 1991; Society for Range Management 1995).

We assessed AS patterns in patchy desert grassland vegetation reflecting either intact or fragmented states (Figs. 1, 2). In grasslands of the Chihuahuan Desert, as in other regions, patches of vegetation and bare ground occur as two-phase mosaics even in an undegraded state due to relatively low resource levels (Aguiar and Sala 1999; Rietkerk et al. 2004). In the context of intact mosaics with limited bare ground, soil function should be preserved, but in fragmented (dysfunctional) mosaics with high connectivity of bare ground, erosion should diminish soil function (and AS). Exposure to erosive forces and reduced productivity in dysfunctional landscapes should degrade both bare soil and soil within adjacent vegetated patches (Tongway and Ludwig 1997a). In this way, indicators assessed at the patch level may reflect broader-scale changes in ecosystems (Northup et al. 1999; Bertiller et al. 2002; Rietkerk et al. 2004).

We evaluated soil aggregate stability and other properties in plots that included the boundaries between vegetated and bare patches (e.g., Watt 1947; Montana 1992; Schlesinger et al. 1996). The plot types were defined according to a general, hypothetical fragmentation model from a matrix of grass containing bare patches (intact area) in which bare patches expand under heavy grazing pressure. This eventually produces a matrix of bare ground surrounding patches of shrubs and/or grass tussocks and finally dead shrubs with eroded soils (fragmented area; Fig. 2). We used the plot classification to test three hypotheses about patterns of AS, specifically: 1) there is a characteristic variation in AS across vegetated-bare patch boundaries that differs among plot types, 2) AS of both vegetated and bare patches declines at some point along the fragmentation sequence, and 3) plot types where AS is high will have high wetting depths after natural rainfall events. We also explored patterns of $\mathrm{pH}$ alongside AS because $\mathrm{pH}$ may influence microbial activity.

\section{METHODS}

\section{Study Area and Assessment of Fragmentation}

We examined a 62 ha area surrounding a sharp ecotone between intact and fragmented areas on the Corralitos Ranch 

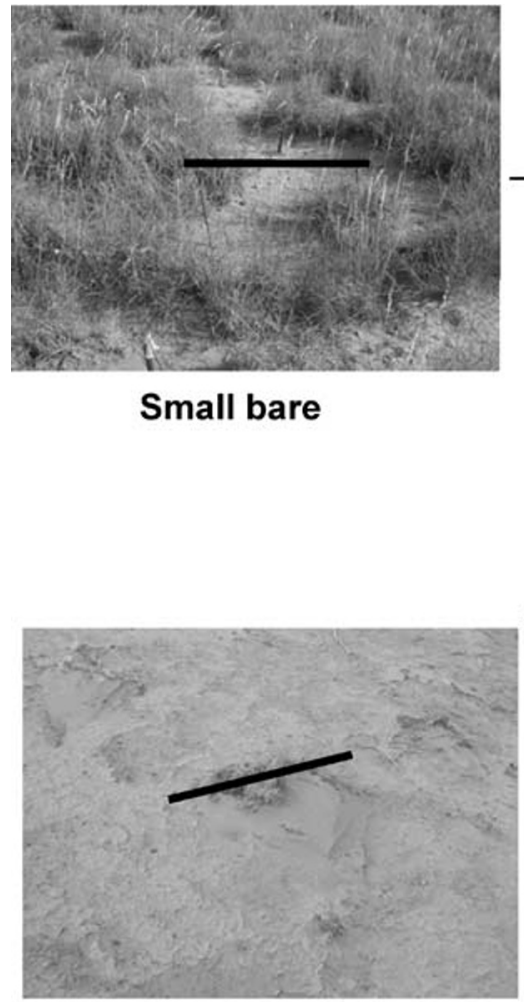

Grass patch
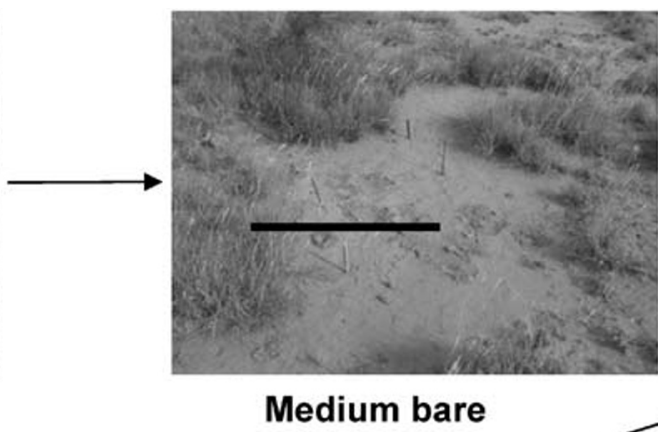

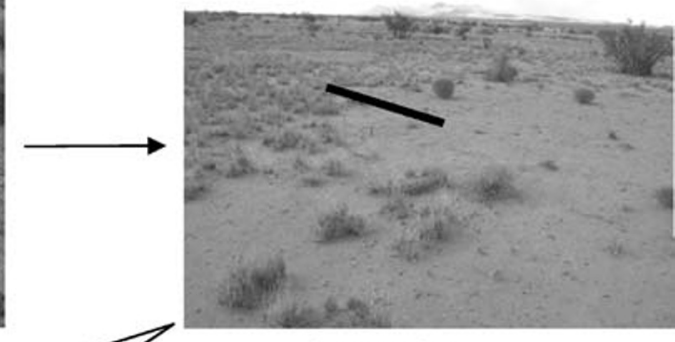

Large bare

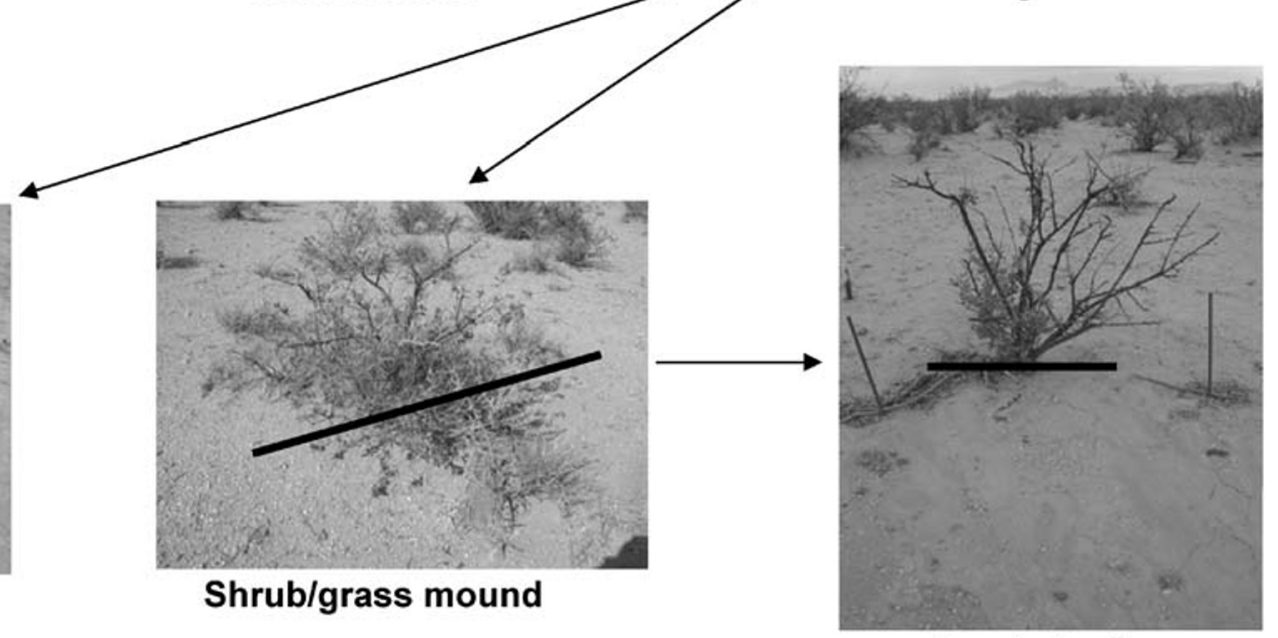

Dead shrub

Figure 2. Plot types and their hypothesized temporal relationships. The top three types are associated with the intact area, the bottom three with the fragmented area. Arrows indicate postulated direction of change during degradation (based on Bisigato and Bertiller 1997; Aguiar and Sala 1999; Rietkerk et al. 2004). Under continuous heavy grazing disturbance and/or drought, plant death leads to increasing bare patch size. Subsequent erosion may eliminate most grasses leaving grasses and remnant/aggraded soils protected by shrubs or remnant grass patches. The death of shrubs may lead to grass death and erosion of soil mounds. The black bars indicate the position of transects used to measure soil aggregate stability profiles.

in Doña Ana County, NM, ca. $25 \mathrm{~km}$ E of Las Cruces, NM, USA (Coordinate system $=$ Universal Transverse Mercator NAD 83 , Zone $=13$, lat $35^{\circ} 80^{\prime} 73^{\prime \prime} \mathrm{N}$, long $31^{\circ} 23^{\prime} 54^{\prime \prime} \mathrm{E}$ ). Mean annual rainfall at the site is $220 \mathrm{~mm}$ but is highly variable from year to year. The study area was defined by manually digitizing the ecotone on a 1996 aerial photograph (U.S. Geological Survey Digital Ortho Quarter Quad; DOQQ) and creating a $300 \mathrm{~m}$ buffer around a $1 \mathrm{~km}$ linear length of the ecotone (Fig. 1). Dominant perennial grasses in the study area included tobosa (Pleuraphis mutica Buckl.), ear muhly (Muhlenbergia arenacea Buckl.), burrograss (Scleropogon brevifolius Phil.), and fluffgrass (Dasyochloa pulchella [HBK] Hitchc.). Shrubs included honey mesquite (Prosopis glandulosa Torr.), tarbush (Flourensia cernua D.C.), Berlandier's wolfberry (Lycium berlandieri Dunal) and creosotebush (Larrea tridentata [DC] Cov.).

Potential grazing pressure is unlikely to have differed between the intact and fragmented areas given the short distances involved and the lack of a fence. The study area was located within a single soil map unit (Berino-Doña Ana association) of the National Cooperative Soil Survey. The two dominant soils constituting this unit were similar and both classified as fine-loamy, mixed, thermic, superactive Typic Calciargids. Based on remnant vegetation, we believe that the composition of the precattle grazing vegetation was similar across the present day ecotone, being dominated by a matrix of P. mutica with patches of mixed C4 bunchgrasses (Bestelmeyer et al. 2006).

We quantified differences in average vegetation cover and soil texture between the intact and fragmented areas in order to characterize fragmentation effects and to test for any systematic differences in surface soil texture that could bias AS estimates (Herrick et al. 2001). We established 300-m long transects consisting of 61 points each (5-m spacing) that were perpendicular to the orientation of the ecotone boundary. The midpoint at $150 \mathrm{~m}$ was located on the boundary (and not considered in subsequent analyses). Transects were spaced randomly along ca. $1 \mathrm{~km}$ of the ecotone. At each point in September-November 2001, we estimated the basal cover of each plant species within each of $196,100 \mathrm{~cm}^{2}$ cells of a $140 \times$ $140 \mathrm{~cm}$ quadrat frame. In the center of each quadrat, we collected a surface soil sample for textural analysis to $5 \mathrm{~cm}$ depth using a $3.8 \mathrm{~cm}$ wide soil auger. Particle-size analysis (PSA) was performed using the hydrometer method (Gee and Bauder 1986).

To quantify differences in fragmentation between each area, we derived 20 classes from the 1996 DOQQ image $\left(1 \mathrm{~m}^{2}\right.$ resolution) using an unsupervised classification (IMAGINE 8.7; 
Table 1. Soil stability classes and criteria adapted from Herrick et al. (2001). Soil samples (5 mm diameter peds) are placed on small sieves (1.5 mm openings in screen) and rapidly dipped into the cells of a plastic box containing distilled water. Samples are rated on a scale from 1 to 6 based on a combination of ocular observations of slaking during the first 5 minutes following immersion into water and the percent remaining on the sieve after 5 dipping cycles at the end of the 5 minute period.

\begin{tabular}{cc}
\hline $\begin{array}{c}\text { Stability } \\
\text { class }\end{array}$ & \multicolumn{1}{c}{ Criteria for assignment to stability class } \\
\hline 1 & $\begin{array}{r}50 \% \text { of structural integrity lost within } 5 \text { seconds of } \\
\text { insertion in water }\end{array}$ \\
2 & $50 \%$ of structural integrity lost $5-30$ seconds after insertion \\
3 & $50 \%$ of structural integrity lost $30-300$ seconds after insertion \\
& or $<10 \%$ of soil remains on the sieve after 5 dipping cycles \\
4 & $10 \%-25 \%$ of soil remaining on sieve after 5 dipping cycles \\
5 & $25 \%-75 \%$ of soil remaining on sieve after 5 dipping cycles \\
6 & $75 \%-100 \%$ of soil remaining on sieve after 5 dipping cycles \\
\hline
\end{tabular}

ERDAS 1999). We reduced these 20 classes to two new classes (bare and vegetated) by comparing individual and contiguous pixels within the classified image to patterns found within the original images. We characterized the current (2004) status of the vegetation and bare soil cover in each of the bare and vegetated classes by sampling $1 \mathrm{~m}^{2}$ plots representing each class in each area ( $\mathrm{n}=80$ for each class). The plot locations were randomly selected with the criteria for inclusion that the selected cell existed within a 25 -cell neighborhood of identical classification to reduce potential error stemming from positional accuracy in the field. This analysis indicated that cells classified as vegetated had (mean $\pm \mathrm{SE}$ ) $16.3 \pm 1.3 \%$ foliar cover of vegetation, whereas cells classified as bare had $3.8 \pm 0.5 \%$. Based on the image analysis, we calculated landscape metrics for the intact and fragmented areas including mean patch size, the size of the largest patch relative to the total cover of the class, and perimeter to area ratio of vegetated area following Turner et al. (2001). Metrics were derived from APACK 2.22 (Mladenoff and DeZonia 2001). Because of the coarse resolution of the imagery and subsequent coarse-scale patch classification $(\geq 1$ $\left.\mathrm{m}^{2}\right)$ relative to the fine patch sizes considered in the plots $(<1$ $\mathrm{m}^{2}$; see below) we used the landscape metrics to characterize broad differences between the intact and fragmented areas rather than the patch neighborhood of the plots.

\section{Plot Types and Measurements}

Initial measurements of AS indicated high variability at fine scales, so we stratified AS measurements within and among six plot types that represented different patch arrangements found within the study landscape (Fig. 2). The plots were selected to cover the study area and were not restricted to transects used for soil texture and vegetation analyses. Three plot types were located in the intact area where bare ground was embedded in a matrix of $P$. mutica (Fig. 1). "Small bare" plots included bare areas that were ca. $0.6 \mathrm{~m}$ in diameter, "medium bare" plots featured bare areas of 1-1.5 m, and "large bare" plots had bare areas of 3-15 m diameter. Each of these plots included part of the P. mutica grass matrix, the relatively discrete boundary between grass and bare ground, and part of the bare ground patch. Three other plot types characterized the fragmented area where grass patches and shrubs occurred in a matrix of bare ground. "Shrub/grass mounds" were centered at the bases of $F$. cernua shrubs that were surrounded by a mound of soil with associated grass and included surrounding non-mound bare soil. Mounds were ca. $50 \mathrm{~cm}$ in diameter and their soils featured evidence of soil deposition coupled with deflation in the surrounding bare soil. The mounds were not associated with rodent activity. "Grass patches" were centered on remnant grass tussocks that were $20-30 \mathrm{~cm}$ in diameter. "Dead shrubs" were similar to shrub/grass mounds, but the mound soil and associated grasses were absent and shrubs were pedestalled (sensu Pyke et al. 2002) by up to $10 \mathrm{~cm}$. Replicates of plot types ( $\mathrm{n}=20$ or 21 in the case of "grass patches") within the intact or fragmented area were selected to be interspersed as much as possible (Fig. 1). AS was assessed at each replicate of each plot type using the field procedure described in Herrick et al. (2001). The stability class values range from 1-6 and describe the increasing resistance of a soil fragment to undergo breakdown in distilled water with and without agitation (Table 1). This technique has been shown to be sensitive to soil disturbance and grass cover when compared to laboratory techniques (Bird et al. 2002).

We sampled AS in each plot replicate on small transects that bisected plots following Fig. 2. Samples were collected every $10 \mathrm{~cm}$ along these transects. Intact area plots were sampled by measuring changes across the boundary from grass tussocks to bare soil. In all cases, the first three points were located on grass and the remainder occurred in the bare area. In the case of small and medium bare plots, transects were $80 \mathrm{~cm}$. In the case of large bare plots, transects were extended to $160 \mathrm{~cm}$. Plots in the fragmented area were sampled by centering transects on either the shrub or grass tussock. Shrub/grass mound transects were $160 \mathrm{~cm}$ long and the others were $80 \mathrm{~cm}$. Thus, the number of points near the center of transects associated with vegetation, mound soil, or interspace soil varied slightly among replicates.

At each sample point (1409 total points), samples of soil aggregates (ca. $4 \mathrm{~mm}$ in diameter) were gathered from two depths a) the soil surface (to $2-4 \mathrm{~mm}$ below the surface) and b) at $2.5 \mathrm{~cm}$ below the surface ( 2818 total samples). Differences in aggregation between these two depths can aid in the interpretation of soil function in arid soils. AS samples were processed in the field in order to minimize mishandling and rupture of soil samples and class values were determined using the soil aggregate stability kit described in Herrick et al. (2001).

AS values were treated as an interval variable and analyzed in two ways. First, we examined variation in AS within each plot type and tested for overall differences in AS values along the small transects ( $\mathrm{n}=20$ points/point position on transects) using general linear models (PROC GLM; SAS 1999; hypothesis 1). Second, we compared values at points located within the vegetated and bare patches (separate analyses) among plot types using mixed models (PROC MIXED; SAS 1999; hypothesis 2). In these analyses, the plot type was the fixed effect, the plot replicate was a random effect, and points in grass or bare ground were subsamples. Post-hoc comparisons of least-squares means were adjusted using the Tukey-Kramer procedure.

We examined soil wetting depth after two storms at 120 points $(5 \mathrm{~m}$ spacing) divided among four randomly-located transects that bisected the ecotone. The large storm $(21 \mathrm{~mm})$ was an intense summer (September) convective shower that 
lasted ca. 20 minutes and generated runoff. The small storm (9.5 $\mathrm{mm}$ ) was a winter (January) frontal storm that lasted several hours and did not generate runoff. Wetting fronts were identified within 12 hours after the storms by digging shallow pits near each point in bare areas and measuring the depth to a sharp color contrast (Bhark and Small 2003). The points were subsequently classified to plot types. The grass patch type was excluded due to inadequate sample size and the shrub/grass mound was split into on-mound and off-mound components. Points falling in rills or significant disturbances (e.g., rodent burrows) were discarded. Values were compared using general linear models with plot type, transect, and transect-by-plot interaction included as model terms (hypothesis 3). Because wetting depth measurements are destructive and we intend to monitor points at which AS was assessed, direct correlation between AS and wetting depth was not attempted.

In addition, we gathered and combined three samples of surface $(0-5 \mathrm{~mm})$ soil from within the vegetated and bare soil patches in 20 replicates of each plot type to test for differences in $\mathrm{pH}$. Soil $\mathrm{pH}$ is significant because it may influence the uptake of mineral nutrients and the activity of microorganisms. In our system, soil erosion and exposure of carbonate-rich horizons may result in increased $\mathrm{pH}$ relative to adjacent, non-eroded soils. pH was determined using an Oakton pHTestr 2 (Oakton Instruments, Vernon Hills, IL, USA). We used a solution of 1:1 soil to water ratio on a volumetric basis. Values were compared using general linear models and Tukey's HSD was used in posthoc comparisons of means.

\section{RESULTS}

\section{Fragmentation and Soil Patterns}

The field measurements and image analysis confirmed our characterization of the intact and fragmented areas (Table 2). The fragmented area had higher cover of bare ground, lower grass cover, larger bare patches, and smaller vegetated patches. In the fragmented area, there was evidence of scouring by wind and water in many bare areas as well as sedimentation at shrub bases and around grass remnants. These indicators were present in the intact area only in the large bare patches. Overall shrub cover was marginally higher in the fragmented area. The relative size of the largest bare patch (a simple metric of bare ground connectivity; Turner et al. 2001) was seven times higher in the fragmented area than in the intact area. Similarly, the perimeter:area ratio of vegetated area (indicating the potential susceptibility of vegetated edges to erosion) was about twice as high in the fragmented area. Surface soil texture, although significantly different for \% silt, varied little between the areas and therefore is unlikely to contribute to a systematic bias in comparisons of AS (Herrick et al. 2001).

\section{Hypothesis 1: Characteristic Variation in Aggregate Stability Within Plot Types}

There was clear and distinctive internal variation within all plot types for surface AS and for most subsurface AS values (Fig. 3). For surface AS, the overall tests for differences among points within a plot type had $\mathrm{P}<0.05$ for every plot type. For subsurface AS, within-plot differences were not significant for grass patch and dead shrub types, but had $\mathrm{P}<0.05$ for the other
Table 2. A comparison of soil texture, ground-based cover, and remotesensed landscape pattern measurements between the intact and fragmented areas (see Fig. 1 and Methods). Values are mean \pm SE.

\begin{tabular}{lccc}
\hline \multicolumn{1}{c}{ Parameter } & Intact & Fragmented & $\mathrm{P}$ \\
\hline Sand in top $5 \mathrm{~cm}(\%$ fine earth) & $66.9 \pm 1.4$ & $69.0 \pm 1.4$ & 0.10 \\
Silt in top 5 cm (\% fine earth) & $19.5 \pm 0.9$ & $17.5 \pm 0.9$ & 0.02 \\
Clay in top 5 cm (\% fine earth) & $13.5 \pm 0.6$ & $13.4 \pm 0.6$ & 0.84 \\
Bare ground cover (\%) & $68.1 \pm 1.9$ & $89.1 \pm 1.9$ & $<0.0001$ \\
Grass basal cover (\%) & $13.0 \pm 0.9$ & $3.0 \pm 0.9$ & $<0.0001$ \\
Shrub basal cover (\%) & $0.15 \pm 0.16$ & $0.64 \pm 0.16$ & 0.09 \\
Mean (SD) bare patch size $\left(\mathrm{m}^{2}\right)$ & $48(189)$ & $143(2283)$ & $\mathrm{NA}$ \\
Mean (SD) vegetated patch size $\left(\mathrm{m}^{2}\right)$ & $623(11246)$ & $91(2613)$ & NA \\
Relative size of largest bare patch & 0.05 & 0.35 & $\mathrm{NA}$ \\
Relative size of largest vegetated patch & 0.98 & 0.70 & $\mathrm{NA}$ \\
Perimeter:area ratio of vegetated area & 0.33 & 0.61 & $\mathrm{NA}$ \\
\hline
\end{tabular}

types. Surface AS values reached their highest values within the vegetated patches of small and medium bare plots. These values dropped by about half in the bare patches of these types, but increased again in the small bare plots as the sample points approached the next vegetated edge. Although the large bare plots showed the same general form, they had consistently lower surface AS values and the differences between vegetated and bare components were less strong.

Surface AS values within the fragmented area never attained the high values observed in the intact area in the small and medium bare plots. Surface values at the bases of shrubs and in grass patches were as low as or lower than surrounding values. Values in shrub/grass mounds, however, were highest in mound areas around the shrub and lower in interspaces. Subsurface AS values were invariant among points in grass patch and dead shrub plots and had similar variability to surface AS in shrub/ grass mounds.

\section{Hypothesis 2: Differences in Soil Aggregate Stability Among Plot Types}

Surface AS values of bare ground patches differed among the plot types $(\mathrm{F}=10.7$; $\mathrm{df}=5,101 ; \mathrm{P}<0.0001)$. Small and medium bare plots had the highest values, whereas large bare plots were lowest (Fig. 4a). Shrub mound and grass patch plot values were intermediate. Interestingly, dead shrub plots had values that were as high as small bare patches. Subsurface values were also different $(\mathrm{F}=2.7 ; \mathrm{df}=5,103 ; \mathrm{P}=0.025)$ and followed the same general pattern but with fewer significant differences (not shown).

Surface AS values of vegetated patches also differed among plot types $(\mathrm{F}=20.1$; $\mathrm{df}=5,104 ; \mathrm{P}<0.0001)$. Small and medium bare plots shared the highest values, and all other types were lower and did not differ from one another (Fig. 4b). Subsurface values also differed $(\mathrm{F}=5.4 ; \mathrm{df}=5,108 ; \mathrm{P}=0.0002)$ and followed the same general pattern but with fewer significant differences (not shown).

\section{Hypothesis 3: Differences in Soil Wetting Depths Among Plot Types}

Wetting front depth differed among plot types after the intense $21 \mathrm{~mm}$ rainfall event (plot term $\mathrm{F}=16.82 ; \mathrm{df}=5,84$; 

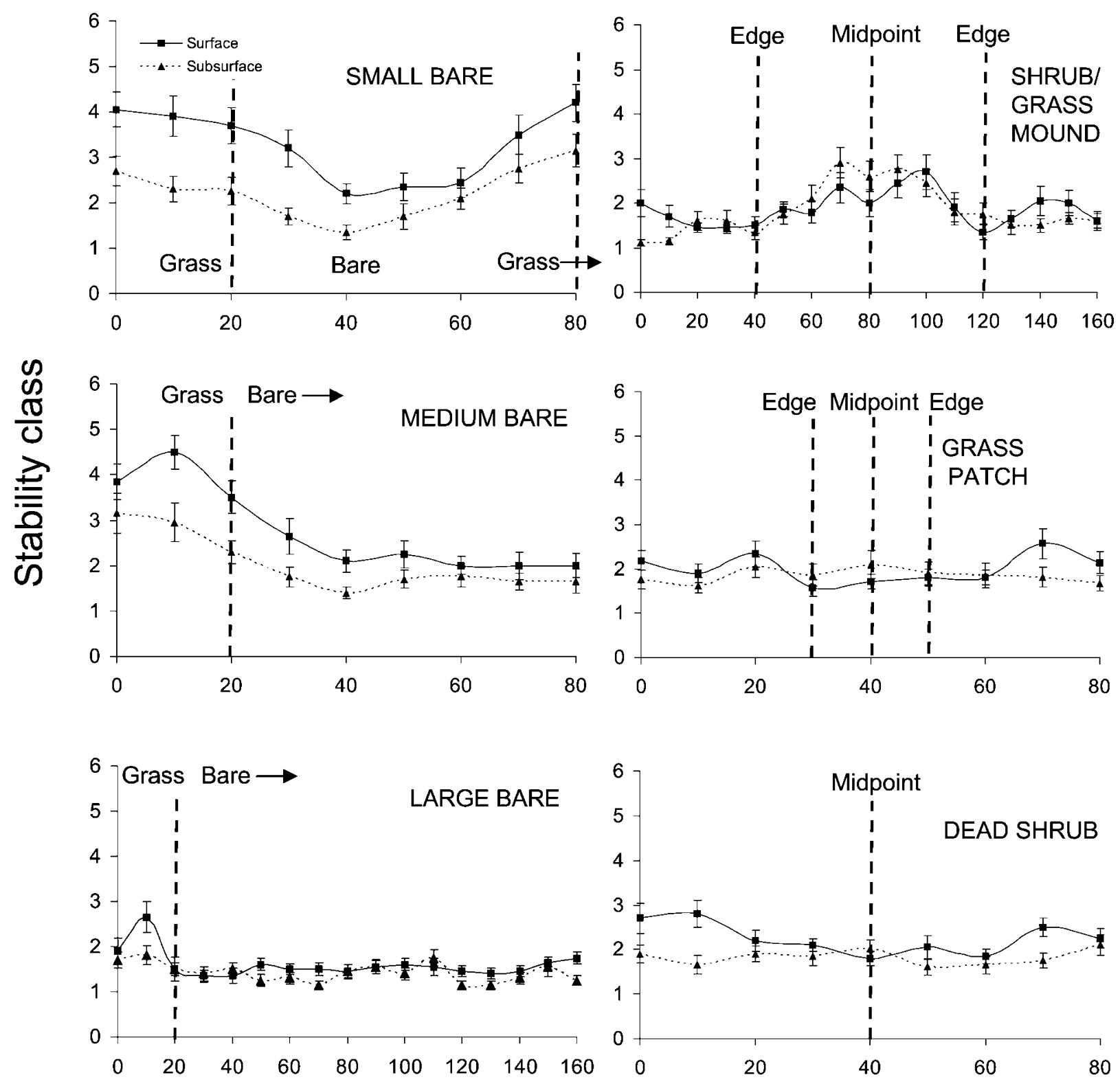

\section{Distance $(\mathrm{cm})$}

Figure 3. Surface and subsurface soil aggregate stability profiles (mean \pm SE) for plot types in the intact (left) and fragmented (right) areas. The dashed line indicates either the break from grass to bare patches (left) or the midpoint and approximate edges of a vegetated patch where the patch boundaries varied (right).

$\mathrm{P}<0.0001)$. Wetting fronts were deepest in small and medium bare plots and the other plot types had shallower wetting fronts that did not differ from one another (Fig. 5). The mean wetting depth for small bare plots was about twice the value of dead shrub plots. Wetting fronts did not differ after the small, frontal rainfall event (patch term $\mathrm{F}=0.46 ; \mathrm{df}=5,84 ; \mathrm{P}=0.81$ ).

\section{Differences in pH Among Plot Types}

$\mathrm{pH}$ values of bare patches $(\mathrm{F}=28.42 ; \mathrm{df}=5,115 ; \mathrm{P}<0.0001)$ and vegetated patches $(\mathrm{F}=18.69 ; \mathrm{df}=5,115 ; \mathrm{P}<0.0001)$ differed among plot types. Values for both bare and vegetated patches were lowest in small bare and medium bare plots and increased from large bare to grass patch, dead shrub, and finally shrub/grass mound plot types (Fig. 4c,d). The range of values along this sequence was from ca. 6.8-7.8.

\section{DISCUSSION}

\section{Variation in Aggregate Stability}

There were clear differences in the AS values for different types of grassland structures. In general, plot types associated with 

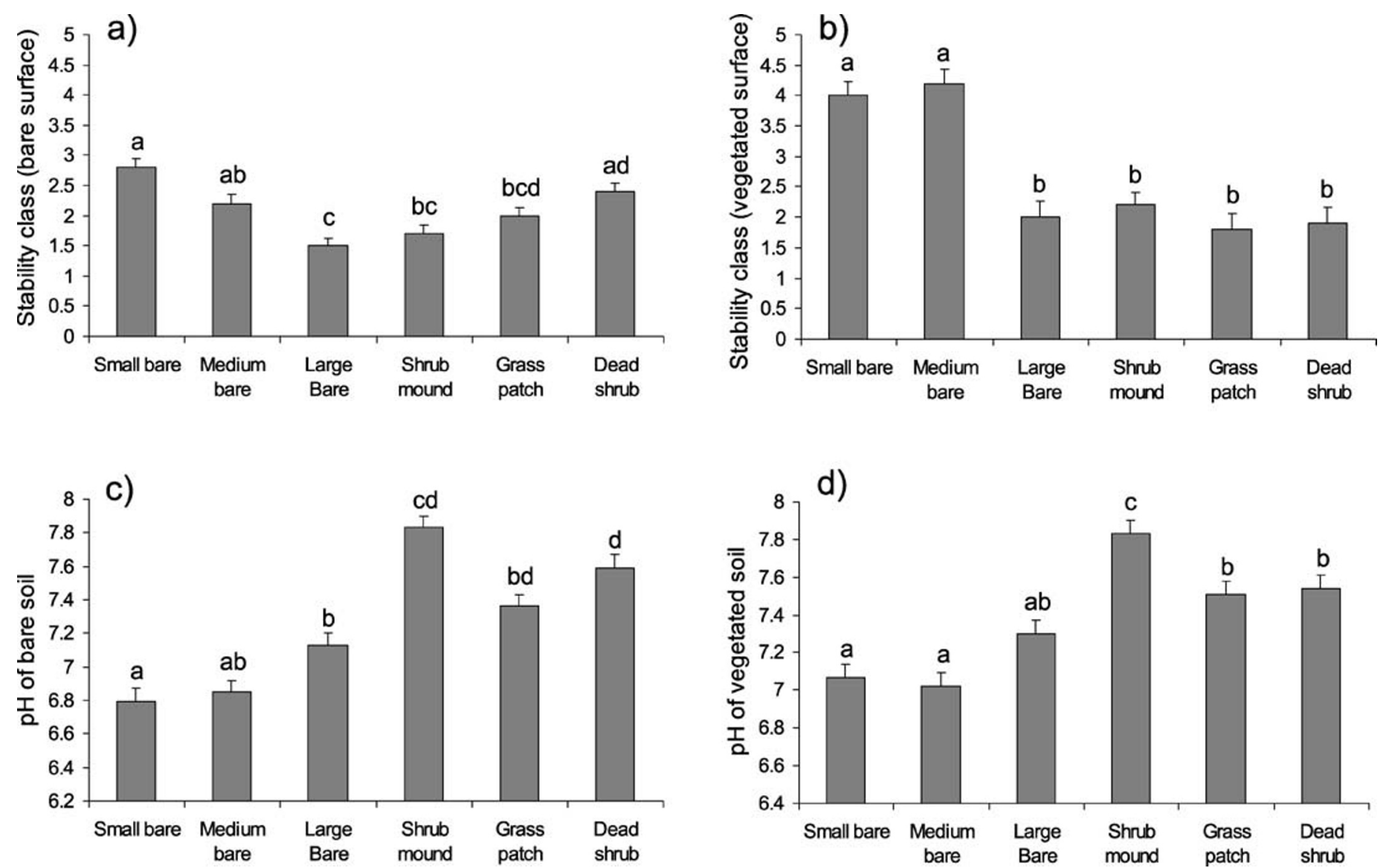

Figure 4. Surface aggregate stability values for bare (a) and vegetated (b) patches and surface pH for bare (c) and vegetated (d) patches in each of the six plot types. Values are mean $\pm \mathrm{SE}$. Bars that do not share the same letter differed at $\mathrm{P}<0.05$.

the fragmented area did not exhibit AS values (in either bare or vegetated patches) as high as those observed in the intact area. Variation in AS across vegetated-bare patch boundaries tended to be lower in the fragmented area than in the intact area. These patterns are consistent with the notion that soils in plots associated with fragmented grassland tend to have reduced function (Tongway and Ludwig 1997a).

Variation of AS within plot types showed that point values for what we classified as "vegetated" and "bare" strata often differed between plots, and therefore, spatial contexts. For example, when bare patches were small there was a clear finescale gradient of change in surface AS even within areas classified as bare ground (e.g., small bare plot of Fig. 3). In other cases (large bare plots), the shift from grass to bare ground values was abrupt and there was little variance in bare ground values with distance away from the patch edge. In still other plots (grass patch and dead shrub), areas away from the vegetated patch had higher surface AS. Thus, the specific position within a plot had a significant influence on AS even after stratifying by vegetated and bare patch types. Patch context is important (Ludwig et al. 2000) and a simple classification of patches into "bare interspace" and "plant" would not have been sufficient to understand variation in soil function.

In general, subsurface AS patterns were a weaker reflection of the surface AS patterns. Subsurface values were often lower than surface values in small and medium bare plot types, but did not differ from surface AS values except around dead shrubs. It is possible that the diminishing contrast between surface and subsurface values reflects the effects of increasing soil disturbance (Herrick et al. 2001).

\section{Changes in Soil Aggregate Stability Along the Hypothetical Fragmentation Sequence}

The high AS values associated with both vegetated and bare patches in the small to medium bare plots are consistent with theories of arid landscape function (Tongway and Ludwig 1997b). Areas featuring small bare patches should be associated with high infiltration rates, low runoff, and low erosion rates (Reid et al. 1999) and increased persistence of vegetation should be reflected in high AS values (Cerdà 1998; Bartès and Roose 2002). In particular, it is notable that mean bare patch AS was higher in the plots with small than in those with large bare patches or a bare ground matrix. This suggests that when the grass matrix is dominant, bare soils are better able to resist erosion not only due to reduced runoff, but due to the higher stability of the bare soil. The higher stability, in turn, may be related to relatively high inputs of organic matter or favorable microclimate for microbial activity (Oades 1988; Ternan et al. 1996; Cerdà 1998).

Our results suggest that AS was significantly reduced when bare patches exceeded ca. $3 \mathrm{~m}$ (even in adjacent grass patches). 


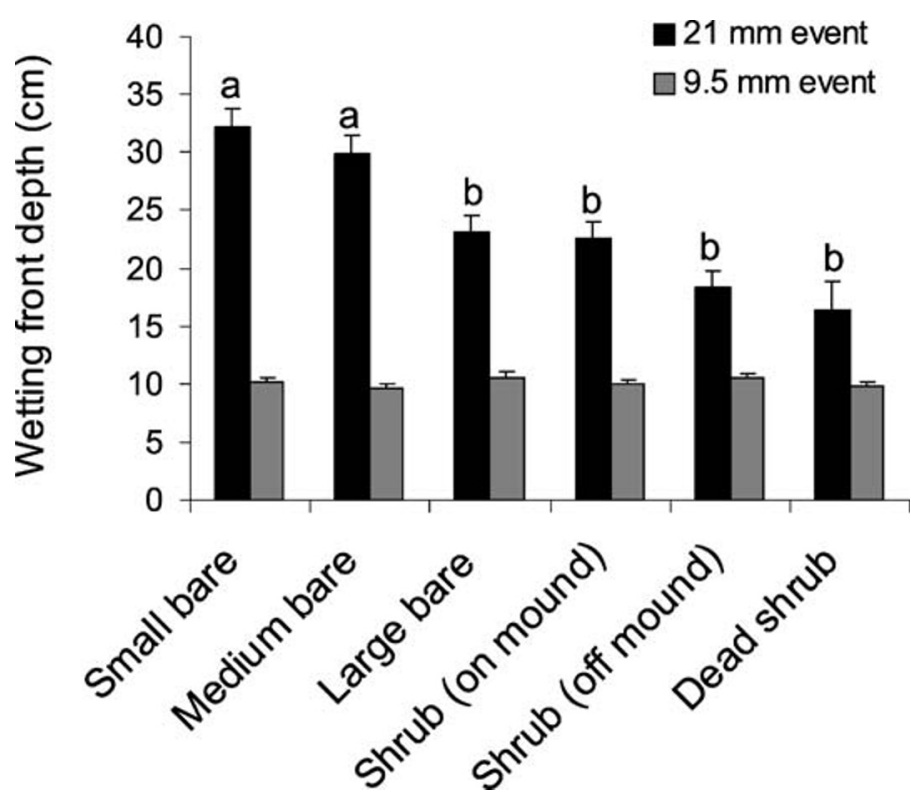

Figure 5. Wetting depths (mean $\pm \mathrm{SE}$ ) in bare areas of patch types after 21 and $9.5 \mathrm{~cm}$ rainfall events. Shrub mounds were divided into on mound and off mound/bare interspace. Samples sizes were small bare $=$ 26; medium bare $=18$; large bare $=14$; shrub (on mound) $=16$; shrub (off mound) $=24$; and dead shrub $=10$. Bars that do not share the same letter differed at $P<0.05$.

The reduced AS in large bare plots paralleled significantly reduced wetting depth compared to small and medium bare plots, suggesting an interpretable relationship between the AS patterns and the key rangeland process of water infiltration. Thus, the large bare plots may be the foci of ongoing fragmentation occurring within what we characterized as intact grassland (and see Bestelmeyer et al. 2006 for evidence of this process). The specific mechanisms producing reduced AS are unknown, but are likely to be due at least in part to a combination of reduced soil organic matter inputs associated with distance from plants, increased losses associated with increased exposure to ultraviolet radiation (Moorhead and Reynolds, 1989), and increased exposure to wind and water erosion. All of these would tend to reduce the soil organic matter pools required for soil aggregation (Tisdall and Oades 1982; Bird et al. 2002). Monitoring and detailed comparisons will be used to investigate these proximate mechanisms, as well as the ultimate mechanisms producing large bare areas (e.g., concentrated patch grazing on certain grasses; Adler et al. 2001).

Eroded bare soils around dead shrubs, however, exhibited intermediate AS values (and shallow wetting depths). Subsequent examination of the soil surface in many of these plots revealed the presence of algal crusts. Although microbiotic crusts should increase AS, they may also decrease infiltration in some cases or colonize previously degraded soils that already had low infiltration rates (Eldridge and Greene 1994). Thus, moderate AS values may be associated with degraded soils and algal crust development.

\section{Relationship of AS to Wetting Depth and $\mathrm{pH}$}

There were clear parallels between AS and the pattern of wetting depth after a storm capable of producing run-off.
Improved wetting depth may be both a cause and a consequence of high AS values related to the low connectivity of bare ground, low overland flow of water and erosion, high organic matter inputs by grass, and consequent improved soil structure (Cerdà 1998). $\mathrm{pH}$ values tended to increase along the fragmentation sequence as AS and wetting depth declined. This may be due to erosion and exposure of relatively carbonate-rich horizons (Bestelmeyer et al. 2006) alongside loss of organic matter inputs. Despite the interesting parallels between AS and $\mathrm{pH}$, the effects of $\mathrm{pH}$ on nutrient sufficiency for desert plants are poorly known (Drenovsky and Richards 2004) and we cannot assert that the differences in the values we observed are ecologically significant (e.g., Hodgkinson 1987).

\section{Implications}

A general transition scenario for arid grasslands holds that bare areas expand under heavy grazing pressure and drought, fragmenting grassland, accelerating water- or wind-governed erosion rates and eventually reducing soil quality needed to support vegetation (Rostagno 1989; Tongway and Ludwig 1997a; Reid et al. 1999; Parizek et al. 2002; Rietkerk et al. 2004; Northup et al. 2005). A key issue, then, is to identify the points in space and time in the fragmentation of grassland where soil degradation (e.g., reduced soil stability and infiltration) takes place that indicates a transition between states. Our results indicate that such soil degradation occurs in sites with bare patches $>3 \mathrm{~m}$ in diameter in our study area, which was dominated by a fine-loamy soil with a $0.5 \%$ slope. Although other arid systems might feature evidence of soil degradation at other bare patch sizes as a function of slope and other properties (Davenport et al. 1998), our work supports the general notion that there is a discontinuous relationship between vegetation cover/bare patch size and soil degradation that might be used to define thresholds.

The clear relationship between our a priori plot classifications, AS, and wetting depth suggest that AS can be used to help operationally define states and points in time at which soil functions are reduced. Although our study cannot address the conditions under which coupled changes in vegetation and soils become irreversible (e.g., Friedel 1991), the significant reductions in AS in areas featuring large bare patches suggest that processes leading to irreversible change may be occurring in specific parts of the landscape and that management adjustments are necessary.

A key problem, however, is to define how AS should be sampled in support of sampling to support STMs, rangeland health assessment, and monitoring. Random sampling (e.g., along randomly-placed transects) to obtain mean values and variances of AS or other properties (Young et al. 1998) may miss important elements of spatial context that provide useful interpretations about the causes of variability. Our results suggest that simple stratification of sampling by carefully-defined plot types that represent different local spatial contexts (e.g., Bisigato and Bertiller 1997; Aguiar and Sala 1999) and then by vegetated and bare patches within those plots may preserve valuable information.

The relationship of AS patterns in plot types to vegetation transitions can be tested via integrated monitoring. For example, if management style is unaltered, we may test whether 
areas featuring initially low AS values $(<3)$ experience relatively high erosion rates and higher rates of grass loss and lower grass recruitment than areas featuring higher initial AS values. We have implemented a monitoring program at the Corralitos study site to examine the relationship between plot type, AS, and erosion and vegetation change. Such tests are critically needed to evaluate the pattern-process relationships built into rangeland health indicators and state-and-transition models used by rangeland managers (Archer and Bowman 2002; Bestelmeyer et al. 2003).

\section{ACKNOWLEDGMENTS}

We thank Julie DiRosario, Elaine Kneller, Ian Kyle, Heather Henshaw, and Jignesh Maun for help in the field and laboratory. Comments from Joel Brown, two anonymous reviewers, David Tongway, and Keith Owens improved the manuscript.

\section{LITERATURE CITED}

Adler, P. B., D. A. Raff, and W. K. Lauenroth. 2001. The effect of grazing on the spatial heterogeneity of vegetation. Oecologia 128:465-479.

Aguiar, M. R., and O. E. Sala. 1999. Patch structure, dynamics and implications for the functioning of arid ecosystems. Trends in Ecology and Evolution 14:273-277.

Archer, S., AND A. Bowman. 2002. Understanding and managing rangeland plant communities. In: A. C. Grice and K. C. Hodgkinson [EDS.]. Global Rangelands: Progress and Prospects. Wallingford, UK: CAB International. p 63-80.

BARTES, B., AND E. ROOSE. 2002. Aggregate stability as an indicator of soil susceptibility to runoff and erosion: validation at several levels. Catena 47:133-149.

BELNAP, J. 1998. Environmental auditing: choosing indicators of natural resource condition: a case study in Arches National Park, Utah, USA. Environmental Management 22:635-642.

Bertiller, M. B., J. O. ARes, and A. J. Bisigato. 2002. Multiscale indicators of land degradation in the Patagonian Monte, Argentina. Environmental Management 30:704-715

Bestelmeyer, B. T., J. R. Brown, K. M. Havstad, G. Chavez, R. Alexander, and J. E. HeRRICK. 2003. Development and use of state-and-transition models for rangelands. Journal of Range Management 56:114-126.

Bestelmeyer, B. T., J. P. Ward, and K. M. Havstad. 2006. Soil-geomorphic heterogeneity governs patchy vegetation dynamics at an arid ecotone. Ecology 87:963-973

Bhark, E., and E. Small. 2003. Association between plant canopies and the spatial patterns of infiltration in shrubland and grassland of the Chihuahuan Desert, New Mexico. Ecosystems 6:185-196.

Bird, S. B., J. E. HerRick, M. M. Wander, and S. F. Wright. 2002. Spatial heterogeneity of aggregate stability and soil carbon in a semi-arid rangeland. Environmental Pollution 116:445-455.

Bisigato, A. J., and M. B. Bertiller. 1997. Grazing effects on patchy dryland vegetation in northern Patagonia. Journal of Arid Environments 36:639-653.

BRISKE, D. D., S. D. Fuhlendorf, And F. E. Smeins. 2005. State-and-transition models, thresholds, and rangeland health: a synthesis of ecological concepts and perspectives. Rangeland Ecology and Management 58:1-10.

CERDÀ, A. 1998. Soil aggregate stability under different Mediterranean vegetation types. Catena 32:73-86.

Davenport, D. W., D. D. Breshears, B. P. Wilcox, and C. D. Allen. 1998. Viewpoint: sustainability of piñon-juniper ecosystems-a unifying perspective of soil erosion thresholds. Journal of Range Management 51:231-240.

Drenovsky, R. E., AND J. H. Richards. 2004. Critical N:P values: predicting nutrient deficiencies in desert shrublands. Plant and Soil 259:59-69.

EldRidge, D. J., AND R. S. B. Greene. 1994. Microbiotic soil crusts: a review of their roles insoil and ecological processes in the rangelands of Australia. Australian Journal of Soil Research 32:389-415.

Emerson, W. W., R. C. Foster, and J. M. OAdes. 1986. Organo-mineral complexes in relation to soil aggregation and structure. In: Interactions of Soil Minerals with Natural Organics and Microbes. Soil Science Society of America Publication 17. Madison, WI: Soil Science Society of America, p 521-548.

ERDAS. 1999. IMAGINE software and on-line help manual. Atlanta, GA: Leica Geosystems.

FrIEDEL, M. H. 1991. Range condition assessment and the concept of thresholds: a viewpoint. Journal of Range Management 44:422-426.

Gee, G. W., and J. W. Bauder. 1986. Particle-size analysis. In: A. Klute [ed.]. Methods of Soil Analysis, Part 1. Physical and Minerological Methods, $2^{\text {nd }}$ ed. Madison, WI: American Society of Agronomy. p 383-411.

Herrick, J. E., W. G. Whitford, A. G. de Soyza, J. W. Van Zee, K. M. Havstad, C. A. SEYBoLd, AND M. WALton. 2001. Field aggregate stability kit for soil quality and rangeland health evaluations. Catena 44:27-35.

Herrick, J. E., J. R. Brown, A. Tugel, P. L. Shaver, and K. M. Havstad. 2002. Application of soil quality to monitoring and management: Paradigms from rangeland ecology. Agronomy Journal 94:3-11.

Herrick, J. E., J. W. Van Zee, K. M. Havstad, and W. G. Whitford. 2005. Monitoring Manual for Grassland, Shrubland and Savanna Ecosystems. Volume I. USDAARS Jornada Experimental Range, Las Cruces, NM. Tucson, AZ: University of Arizona Press. $36 \mathrm{p}$.

Hodgkinson, H. S. 1987. Relationship of saltbush species to soil chemical properties. Journal of Range Management 40:23-26.

Holm, A. M., L. T. Bennett, W. A. Loneragan, and M. A. Adams. 2002. Relationships between empirical and nominal indices of landscape function in the arid shrubland of western Australia. Journal of Arid Environments 50:1-21.

Karl, M. G., D. A. Pyke, P. T. Tueller, G. E. Schuman, M. R. Vinson, J. L. Fogg, R. W. Shafer, S. J. Borchard, W. G. Ypsilantis, and R. H. Barrett, JR. 2003. Chapter II: Indicators for Soil and Water Conservation on Rangelands. 2003 Sustainable Rangelands Roundtable First Approximation Report. URL http:// sustainablerangelands.warnercnr.colostate.edu/2003Report/2003Report.htm, accessed 7 October 2005.

LudWig, J. A., J. A. Wiens, and D. J. Tongway. 2000. A scaling rule for landscape patches and how it applies to conserving soil resources in savannas. Ecosystems 3:84-97.

Ludwig, J. A., B. P. Wilcox, D. D. Breshears, D. J. Tongway, and A. C. Imeson. 2005. Vegetation patches and runoff-erosion as interacting eco-hydrological processes in semiarid landscapes. Ecology 86:288-297.

Maestre, F. T., AND J. Cortina. 2004. Insights into ecosystem composition and function in a sequence of degraded semiarid steppes. Restoration Ecology 12 494-502.

Mladenoff, D. J., and B. DeZonia. 2001. APACK analysis software and user's guide. Madison, Wl: University of Wisconsin. $50 \mathrm{p}$.

Montana, C. 1992. The colonization of bare areas in two-phase mosaics of an arid ecosystem. Journal of Ecology 80:315-327.

Moorhead, D. L., AND J. F. ReYnoLds. 1989. Mechanisms of surface litter mass loss in the northern Chihuahuan Desert: a re-interpretation. Journal of Arid Environments 16:157-163.

Northup, B. K., J. R. Brown, and J. A. Holt. 1999. Grazing impacts on the spatial distribution of soil microbial biomass around tussock grasses in a tropical grassland. Applied Soil Ecology 399:1-12.

Northup, B. K., C. D. Dias, J. R. Brown, and W. C. Skelly. 2005. Micro-patch and community scale spatial distribution of herbaceous cover in a grazed eucalypt woodland. Journal of Arid Environments 60:509-530.

OADES, J. M. 1984. Soil organic matter and structural stability: mechanisms and implications for management. Plant and Soil 76:411-423.

OADES, J. M. 1988. The retention of organic matter in soils. Biogeochemistry 5:35-70.

OAdes, J. M., and A. G. Waters. 1991. Aggregate hierarchy in soils. Australian Journal of Soil Research 29:815-828.

Parizek, B., C. M. Rostagno, and R. Sottini. 2002. Soil erosion as affected by shrub encroachment in northeastern Patagonia. Journal of Range Management 55:43-48. 
Pierson, F. B., JR., and D. J. Mulla. 1990. Aggregate stability in the Palouse region of Washington: effect of landscape position. Soil Science Society of America Journal 54:1407-1412.

Pierson, F. B., JR., W. H. Blackburn, S. S. Van Vactor, and J. C. Wood. 1994. Incorporating small scale spatial variability into predictions of hydrologic response on sagebrush rangelands. In: W. H. Blackburn, F. B. Pierson, Jr., G. E. Schuman, and R. Zartman [EDS.]. Variability in rangeland water erosion processes. Madison, WI: Soil Science Society of America. p 23-34.

Pyke, D. A., J. E. Herrick, P. Shaver, and M. Pellant. 2002. Rangeland health attributes and indicators for qualitative assessment. Journal of Range Management 55:584-597.

Reid, K. D., B. P. Wilcox, D. D. Breshears, and L. MacDonald. 1999. Runoff and erosion in piñon-juniper woodland: influence of vegetation patches. Soil Science Society of America 63:1869-1879.

Rietkerk, M., S. C. Dekker, P. C. de Ruiter, and J. van de Koppel. 2004. Selforganized patchiness and catastrophic shifts in ecosystems. Science 305: 1926-1929.

Rostagno, C. M. 1989. Infiltration and sediment production as affected by soil surface conditions in a shrubland of Patagonia, Argentina. Journal of Range Management 42:382-385.

SAS INSTITUTE, INC. 1999. SAS/STAT Software, Changes and Enhancements through Release 6.12. Cary, NC: SAS Institute, Inc. 1848 p.

Schlesinger, W. H., J. A. Raikes, A. E. Hartley, and A. F. Cross. 1996. On the spatial patterns of soil nutrients in desert ecosystems. Ecology 77:364-374.

Society for Range Management, Task Group on Unity in Concepts and Terminology. 1995. New concepts for assessment of rangeland condition. Journal of Range Management 48:271-282.

Spaeth, K. E., F. B. Pierson, J. E. Herrick, P. L. Shaver, D. A. Pyke, M. Pellant, D. Thompson, and B. Dayton. 2003. New proposed national resources inventory protocols on nonfederal rangelands. Journal of Soil and Water Conservation 58:18A-21A.

Ternan, J. L., A. G. Williams, A. Elmes, and R. Hartley. 1996. Aggregate stability of soil in central Spain and the role of management. Earth Surface Processes and Landforms 21:181-193.

TISDALL, J. M., AND J. M. OADES. 1982. Organic matter and water-stable aggregates in soils. Journal of Soil Science 33:141-163.

Tongway, D. J., AND J. A. LudwiG. 1997a. The nature of landscape dysfunction in rangelands. In: J. Ludwig, D. Tongway, D. Freudenberger, J. Noble, and K. Hodgkinson [EDS.]. Landscape Ecology: Function and Management: Principles from Australia's Rangelands. Collingwood, Victoria, Australia: CSIR0 Publishing. p 49-62.

Tongway, D. J., AND J. A. LudWIG. 1997b. The conservation of water and nutrients within landscapes. In: J. Ludwig, D. Tongway, D. Freudenberger, J. Noble, and K. Hodgkinson [EDS.]. Landscape Ecology: Function and Management: Principles from Australia's Rangelands. Collingwood, Victoria, Australia: CSIRO Publishing. p 13-22.

Tongway, D. J., AND N. L. HindeEy. 2004. Landscape function analysis manual: procedures for monitoring and assessing landscapes with special reference to minesites and rangelands. Version 3.1. Canberra, Australia: CSIRO Sustainable Ecosystems. $80 \mathrm{p}$.

Turner, M. G., R. H. GardneR, and R. V. O'Neill. 2001. Landscape Ecology in Theory and Practice: Patterns and Processes. New York, NY: Springer-Verlag. 401 p.

van de Koppel, J., M. Rietkerk, And F. J. Weissing. 1997. Catastrophic vegetation shifts and soil degradation in terrestrial grazing systems. Trends in Ecology and Evolution 12:352-356.

WATT, A. S. 1947. Pattern and process in the plant community. Journal of Ecology 35:1-22.

Westoby, M., B. Walker, and I. Noy-Meir. 1989. Opportunistic management for rangelands not at equilibrium. Journal of Range Management 42:266-274.

Wilcox, B. P., D. D. BReshears, AND C. D. Allen. 2003. Ecohydrology of a resourceconserving semiarid woodland: effects of scale and disturbance. Ecological Monographs 73:223-239.

Young, F. J., R. D. Hammer, and F. Williams. 1998. Evaluating central tendency and variance of soil properties within map units. Soil Science Society of America Journal 62:1640-1646. 